\title{
Korean Punctuation Systems
}

\author{
Jeon Kyung LEE \\ Yonsei University \\ ljk0201@gmail.com
}

\begin{abstract}
Currently, the concept of punctuation marks organized by the National Institute of Korean Language involves minimum punctuation marks that help communication between a writer and a reader. There are no traditional marks and instead, all of them reflect the Western punctuation marks. The former reflects the writer's situation and functions in a sentence unit while the latter functions in a text unit which is related to the reading activity. The Korean traditional punctuation marks indicate the result of understanding the text. This means that Korean punctuation marks were developed in connection with learning. The punctuation was developed, at first, from making the punctuation marks in order to understand Chinese when the Koreans accepted Chinese letters. Further, whenever they faced new letters, they developed several kinds of marking. This is why there is a conceptual gap between the traditional punctuation and the current punctuation marks. This research thoroughly examines Korean traditional punctuation marks and discusses how Korean traditional punctuations can be classified in the same category with the current punctuation marks.
\end{abstract}

Keywords: Korean punctuation; Korean traditional punctuation; transition of Korean punctuation system; kugyol

\section{Povzetek}

Trenutno pojem ločil, ki jih je Nacionalni inštitut za korejski jezik organizirano vključuje minimalne oznake ločila, ki pomagajo komunikacijo med pisatelja in bralca. Ni tradicionalne oznake, in namesto, vse od njih odražajo Zahodnega ločil.Nekdanji odraža stanje in funkcije pisca $\mathrm{v}$ stavku enoti, medtem ko slednjih funkcij v besedilno enoto, ki je povezano $\mathrm{z}$ dejavnostjo branja. Korejske tradicionalne ločila kažejo rezultat razumevanja besedila. To pomeni, da so bili korejski ločila razvija v povezavi z učenjem.Ločil se je razvila na prvi, od česar se ločila, da bi razumeli, kitajski, ko Korejci sprejeli kitajske črke. Nadalje, kadar se soočajo nova pisma, so razvili več vrst označevanja. To je razlog, zakaj obstaja pojmovna razlika med tradicionalnim ločil in sedanjimi ločil. Ta raziskava temeljito preučuje korejske tradicionalne ločila in opisuje, kako korejski tradicionalni ločila mogoče uvrstiti v isto kategorijo $\mathrm{z}$ veljavnimi ločil.

Ključne besede: korejska ločila; korejska tradicionalna ločila; razvoj korejskega sistema ločil; pisava kugyol 


\section{Introduction}

Written texts in Korea have 2000 years of history. These texts vary in form, ranging from epigraphs and wooden and stone inscriptions to paper books. Many marks and Chinese characters are used in these texts.

Some marks are still applied in the same form but most of them are not. Traditional Korean writing system underwent drastic changes from the 19th to $20^{\text {th }}$ centuries, in that during this time, along with Chinese characters and Hanguel, Roman alphabets and Japanese Kana letters were used as well. The end of the 19th century in Korea also saw the import of the western writing direction and punctuation marks.

Some magazines and newspapers played significant roles in the influx of the western punctuation marks. Especially, the publication of Dongnip Sinmun [The Independent News] spurred the burgeoning use of the western punctuation marks, and it contributed to the imported punctuation marks being included in the Draft of Unified Korean Spelling System in 1933. Modern Korean punctuation marks were influenced from Modern Chinese and Japanese punctuation marks. The standardization of the Korean punctuation has been executed several times, and by now it is organized into seven categories of functions with twenty marks, quite similar to the western punctuation.

However, as the standardization process progressed, the traditional Korean punctuation named Kudu-jeom (구두점, 句讀點) steadily lost its ground as a punctuation system, and now even its vestige is barely found in the current Korean punctuation. New marks, including $<,>, \therefore, \because$, ex (e.g.), $※, \wedge$, have been employed by Koreans in their daily communication, and these marks work as lexical designators or as carriers of the writer's intentions or sentiments, just as many of traditional Korean punctuation marks did so. Therefore, I believe that investigating the old marks and comparing them with these new marks will provide us with the opportunity to reexamine the legacy and efficacy of punctuation systems.

\section{Korean punctuation in Ancient times (? $7^{\text {th }}$ century)}

Most of Korean texts in ancient times were administrative documents, which consisted of Chinese characters. Even though many documents about history or governance were left on gravestones, these texts show direct physical differences in word spacing and changing the paragraph, but does not show the use of specific marks. Recently, hundreds of wooden documents were excavated and have been studied, which show that some form of marks were used to separate paragraphs or different elements.

Division lines for separating paragraphs, as seen in oracle bone scripts, can be seen in Korean wooden documents. Punctuation marks found in wooden documents were not only Inversions Mark $(\sqrt{ })$ introduced by Lee (2002) but also topic indicator (, $\neg$ '), text indicator ' - , $\perp$ ' by Lee (2006), item indicator (云) <Picture $1>$ and ' $\circ, \vee, 一 . \diamond, \ddagger$ ' by Son (2011). Besides these, paragraph distinguisher ' $\bullet$ ' and repetition marker ' $=$ ' have 
many examples (Lee (2005):1-17). Such as ' $\bullet,-,=, \sqrt{ }$ 'were used in common throughout the East Asia ${ }^{1}$. Among these '- ' is a simple line separating different elements (Picture 2). ' ᄀ'style or ' $了$ 'style of elements indicator (Picture 3) and ' 0 ' of deletion and correction marks were used in common throughout the East Asia. The former, which indicates either the overlapped elements or confirmed content, might be used as confirmation marks in administrative documents. ' 0 ' was used in Silla village documents to indicate corrections or deletions (Picture 4). These two marks were continued to be used even after the medieval times.
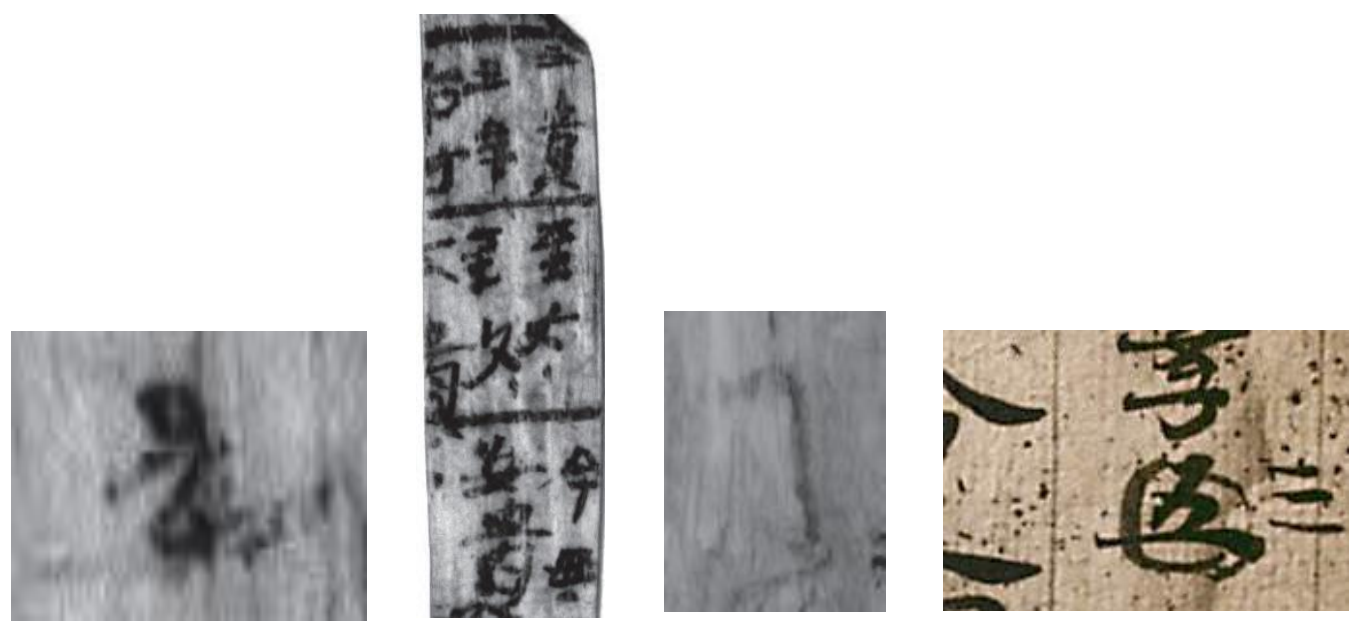

Picture 1-4 (left to right): Punctuation marks in wooden documents.

Like this, all the ancient documents were transcribed and had a basic purpose of reporting. Therefore, it was important to deliver the truth or the fact without any misinterpretation with limited methods. This is a way to increase efficiency of administrative reports and commercial reports under lack of mastery of Chinese characters. The punctuation marks for separating paragraphs or marking different elements were a requirement in this era. Thus, in the ancient documents, marks other than those that represents correction or omission of repetitive letters were not found for several reasons. Above all, there aren't many wooden documents found to be studied. Also, marks that separates texts or distinguishes different elements such as lines or dots are more significant because the text strived for simplicity and clarity.

\footnotetext{
${ }^{1}$ Marks such as $' \cdot,-,=, \sqrt{ }$ ' appear in the wooden documents of Qin Dynasty in China. Each of them has its own function: paragraph distinguisher, boundary marker, repetition marker, and Inversions mark.
} 


\section{Punctuation in the Middle Ages $\left(8 \sim 15^{\text {th }}\right.$ century)}

As discussed earlier, the number of punctuation marks were not diverse in the early stage of the development of the writing system. It can be assumed that the punctuation marks developed from the unit of a word to the unit of sentences. After the medieval time, punctuation marks take role as an aid for learning as well as the document reporting. Various signs and marks were developed for the purpose of learning and interpretation of the Chinese characters. Great number of punctuation marks appeared regarding sentence structure, separation, and correction as well as supplement marks for translation into Korean.

As Koryeo Dynasty(10 14 ${ }^{\text {th }}$ century) imposed the public examination system, studying Chinese characters became essential to the ruling class. Koreans invented kugyol to understand and study Chinese character texts better. It is one type of borrowed character writing system, which is made to interpret Chinese character text. The place where the kugyol is marked is the space between the lines of Chinese character text, and is where punctuation mark is marked.

Currently, kugyol is recognized as a letter in Korea. However, kugyol, added to Chinese text, worked as punctuation marks. Chinese character was 'Lingua Franka' in East Asia, kugyol letters was used merely as interpretative marks to understand Chinese text. Before inventing Hanguel (Korean writing system), the fact that kugyol character had never been used independently to write Korean sentences shows that Koreans did not regard kugyol as a whole character. The Korean word of kugyol-kugyol is a word borrowed from the Chinese-is Ipgyeot and means 'reading postposition'.

Along with kugyol, many kinds of punctuation marks have emerged, and interpretative marks were used widely. Yu(1989), Lee(1995), Lee(2002) studied traditional punctuation marks. These punctuation marks can be categorized by functions and editions as in Table1. Punctuation marks working in text unit were widely used regardless of being printed or scripted. 
Table 1: The Korean traditional punctuation

\begin{tabular}{|c|c|c|c|c|c|}
\hline Unit & Mark & Name & Function & $\begin{array}{l}\text { Printed/ } \\
\text { Written }\end{array}$ & $\begin{array}{l}\text { Other } \\
\text { ways of } \\
\text { markin } \\
\mathrm{g}\end{array}$ \\
\hline \multirow{4}{*}{$\begin{array}{l}\text { Text } \\
\text { Unit }\end{array}$} & ○ & wongweon 圓圈 & dividing texts, indicating elements & printed & $\begin{array}{l}\text { Chan- } \\
\text { ging } \\
\text { line }\end{array}$ \\
\hline & 锋: & $\begin{array}{l}\text { Eummun } \\
\text { 陰文 }\end{array}$ & $\begin{array}{l}\text { dividing texts, indicating elements, } \\
\text { emphasizing }\end{array}$ & printed & \\
\hline & $\circ$ & $\begin{array}{l}\text { Kwanju } \\
\text { 貫珠(連圈) }\end{array}$ & indicating main topic, emphasizing & written & $\$$ \\
\hline & $\bullet$ & $\begin{array}{l}\text { Pi-jeom } \\
\text { 批點(連點) }\end{array}$ & indicating sub- topic, emphasizing & written & \\
\hline \multirow{10}{*}{$\begin{array}{l}\text { Sente } \\
\text { nce } \\
\text { Unit }\end{array}$} & $\circ$ & $\begin{array}{l}\text { Saseong-jeom } \\
\text { 四聲點 }\end{array}$ & $\begin{array}{l}\text { marking intonation (of Chinese } \\
\text { characters) }\end{array}$ & $\begin{array}{l}\text { printed, } \\
\text { written }\end{array}$ & \\
\hline & $\circ$ & $\begin{array}{l}\text { Korit- } \\
\text { jeom 고릿점 }\end{array}$ & dividing sentences and phrases & $\begin{array}{l}\text { printed, } \\
\text { written }\end{array}$ & \\
\hline & $\bullet$ & Pang-jeom 방점 & $\begin{array}{l}\text { marking intonation (of Korean } \\
\text { expression) }\end{array}$ & printed & \\
\hline & | & $\begin{array}{l}\text { Chageodeup- } \\
\text { phyo 자거듭표, } \\
\text { 疊字符) }\end{array}$ & marking for a repeated letter & $\begin{array}{l}\text { printed, } \\
\text { written }\end{array}$ & $<, " \prime$ \\
\hline & 1 & $\begin{array}{l}\text { Keochim- } \\
\text { phyo 거침표(經 } \\
\text { 由符) }\end{array}$ & marking confirmation & written & \\
\hline & $\smile$ & $\begin{array}{l}\text { Mukeum- } \\
\text { phyo 묶음표 }\end{array}$ & Combining different elements & written & \\
\hline & $\circ$ & $\begin{array}{l}\text { Kium- } \\
\text { phyo 끼움표(插 } \\
\text { 入符) }\end{array}$ & insertion, correction & written & $\Delta$ \\
\hline & ] & Sakjebu 삭제부 & deletion & written & $\square, \circ$ \\
\hline & ○ & $\begin{array}{l}\text { Keokjabu 격자 } \\
\text { 부 }\end{array}$ & spacing & written & 8 \\
\hline & space & Kongkyeok 공격 & marking honorific & $\begin{array}{l}\text { printed, } \\
\text { written }\end{array}$ & 擡頭法 \\
\hline
\end{tabular}


Punctuation marks working in text unit were widely used regardless of being printed or scripted. Correction marks working in sentence unit were mostly reported, and appear in various ways. ' $\circ$ ' (korit-jeom) or ' $O$ ' (weon-gweon), which were used frequently, have various functions. ' $\circ$ ' (korit-jeom) can be used as phrase or sentence mark based on where it is placed in a sentence, and marking intonation based on which part of Chinese character is marked. Also, ' $O$ ' (weon-gweon) is used to distinguish Chinese text from Eonhe (Korean translation text). It can also be used to separate elements and marking spacing. The tendency to use few marks efficiently triggers several changes in the traditional punctuation marks. However, traditional punctuation marks were used as it was suggested in printed documents because the use of these was normative.

Along with Kugeol, numerous numbers of marks were used to aid Kugeol letters in order to help people understand contents in kugyol text more clearly. Generally, kugyol is used as a terminology that encompasses all the Chinese character interpretation law. Indeed, several different marking systems are used in Kugeo. Based on these systems, kugyol can be grouped into Chatokugyol (Chinese character kugyol, Hangeul kugyol) and cheomto kugyol ${ }^{2}$. Moreover, genuine marks which cannot be replaced to language immediately are also included in a marking system. Kugeol system that function as a help to understand and interpret sentences. Table 2 shows those interpretative marks in Kugeol text.

Table 2: The Marks in Kugeol text ${ }^{3}$

\begin{tabular}{|c|c|c|c|}
\hline Name & Form & Function & distribution \\
\hline Happu 합부 & $/, 1$ & One word & $\begin{array}{l}\text { chato, } \\
\text { cheomto }\end{array}$ \\
\hline Yeokdokjeom 역독점 & . & Interpret order & Chato \\
\hline Yeokdokseon 역독선 & $\backslash, /, 1$ & Interpret order & cheomto \\
\hline Chisiseon 지시선 & $\backslash, /$ & Interpret order & cheomto \\
\hline Chungbokseon 중복선 & $\backslash, /$ & Duplication of code & cheomto \\
\hline Kyeonggeson 경계선 & $1,-, \neg \ldots$ & Boundary of character & cheomto \\
\hline Pochungseon 보충선 & - & Supplement of verb & cheomto \\
\hline $\begin{array}{l}\text { Sulmokkubunseon } \\
\text { 술목구분선 }\end{array}$ & - & $\begin{array}{l}\text { Boundary indicator of verb } \\
\text { and object }\end{array}$ & cheomto \\
\hline Pichimseon 삐침선 & $\searrow$ & $\begin{array}{l}\text { Interpretation indicatorsuch } \\
\text { as'営, }\end{array}$ & cheomto \\
\hline
\end{tabular}

${ }^{2}$ Chatokugyol uses traditional letters but cheomto Kugyol is the code system using sign such as ., $: . /, \backslash$, etc. and the place where these signs will be marked.

${ }^{3}$ It can be seen that marks of cheomto-Kugyol appear a lot more than marks of chato-Kugyol among many marks in <table2>. It is why the former-it is code- needs more complementary marks. 
Additionally, other various punctuation marks appear in some documents. Reading order marks are commonly known. The reading orders of Chinese character were marked as '一, 二, 三', and we can find these marks in the left side of thechinese characters (Picture 5). Correction marks are also a common form. There is a small Korit-jeom $\left(^{\circ}\right)$ located on the upper part of '五', and a small '三' is marked on the right side as a correction (Picture 6). Sometimes, Korit-jeom is marked on the right side of the letter being corrected, and corrected letter is written at the margins of a book. Often, people write their own marks instead of ordinary punctuation marks in order to distinguish boundary of sentences (Picture 7). The form of having tail on ' 8 ' is written on both upper and lower side of repeated '無無'. It is assumed that in order to eliminate a possibility of misinterpreting, they used the mark in addition to an interrogative ending' $\rho$ ' even though a boundary of sentence between '無無' can be indicated by using only an interrogative ending' $\rho$ '. It indicated the sentence that the letter belong to by drawing lines on the upper and lower side of ' 8 '.
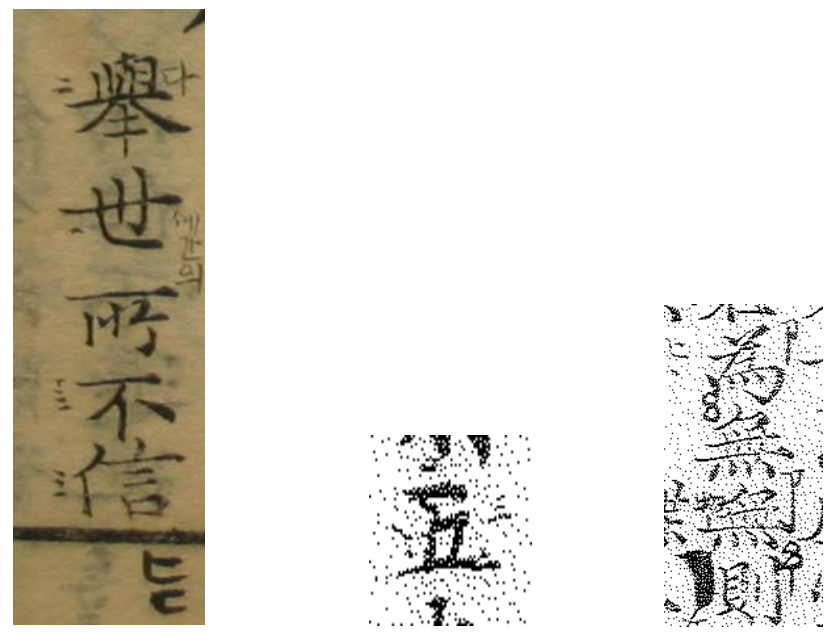

Picture 5-7 (left to right): Examples of punctuation marks.

\section{From Traditional Punctuation Systems to Modern Ones}

The western style of Korean punctuation marks have been expanded through the public education and press media as the western punctuation system was introduced through Japan.

\footnotetext{
${ }^{4}$ This can be completely different meaning. A mark that looks like 8 is connected is called Kwanju or Yeongweon. The mark is mostly used to mark a beginning or a topic of a text.
} 
『 친목회회보 Chinmokhwe-hwebo 』(1896) 5 and 『 신정심상소학 Sinjeongsimsangsohak』(1896) ${ }^{6}$ are the first instances of using the western punctuation marks, and these are deeply related to Japan. ${ }^{7}$

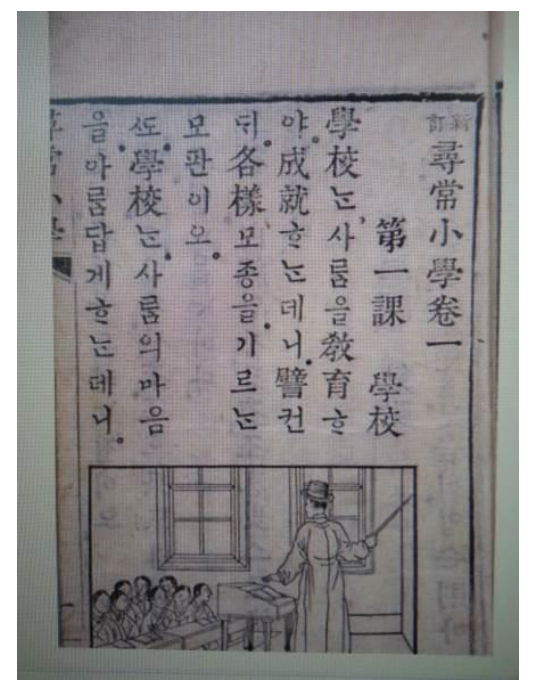

Picture 8: Western punctuation marks firstly used.

\section{(1) 親睦會序說朴正秀}

聖人作易、列同人比二封焉시니、夫比者、天地保合大和之道也 I 라、萬人相比 、推尊一人而成君國고、萬國相比、各保一國而成世界니、是以各國各人之相離 而不比者、郎失天之和而爲其所不容咕、各國各人之相合而同比者、即順天地 之和而爲其所黙佑나니。

(『친목회회보 Chinmokhwe-hwebo』1-1,1896)

(2)

學校 $\square$ 。사 $\square$ 을 呚育 $\square$ 야。成就 $\square \square$ 데니。譬컨 $\square$ 。各樣모종을。기르 $\square$ 모판이요。 學校 $\square$ 사 $\square$ 의마음을。아 $\square$ 답게 $\square \square$ 데니。譬컨 $\square$ 。各色물드리·집이오。

(『신정심상소학 Sinjeongsimsang-sohak』, 1896)

\footnotetext{
${ }^{5}$ A social magazine for Korean students who study in Japan.

${ }^{6}$ (Picture 8) A textbook published by the Ministry of Education (Hakbu) of The Great Korean Empire.

${ }^{7}$ In the introduction, 『신정심상소학 Sinjeongsimsangsohak』 was explained as a textbook made by a Japanese editor. Comparing the the two textbooks, the places where punctuation marks were used are almost identical (Kim 1980).
} 
There is possibility that western punctuation marks were used much earlier than in Christian religion related book, 『한영자전 Korean-English Dictionary』(Picture 9), written by Underwood in 1890) can be found in other documents that have not been studied yet. It should be noted that this is the time when both the traditional punctuation marks and the western punctuation marks were used together. For example, the traditional punctuation marks are printed in a wooden-printed Taoism scripture, 『남궁계적 Namgunggejeok』(1876). The use of western punctuation marks appear far later in the Bible, which was publicly more accessible in Korea than dictionaries.
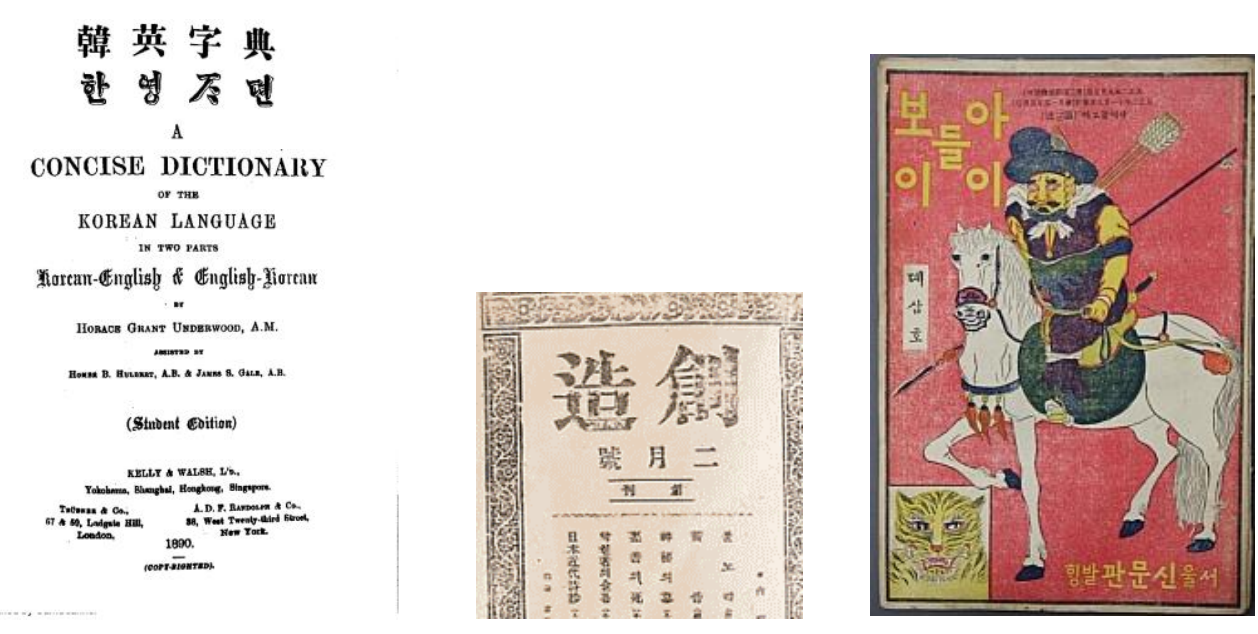

Picture 9-11 (left to right): Examples of diversity of cover layouts

(1), (2) were both affected by Japanese printing system which used punctuation marks even before the translated Christian Bible which was influenced by western culture. After that, korit-jeom (。 ) and mo-jeom (、) have been used variously in many newspapers and magazines. Spacing between a word and question mark can be found the 『창조 Changjo』(1919) magazine, as in (3) below ${ }^{8}$.

(3)

아날이저믄다、西便하늘에、외로운江물우에 、스러져가는분홍빗놀..........

아아해가저믈면해가저믈면 날따다살구나무그늘에혼자우는밤이 •

오것마는、오늘은四月이라제일날、

큰길을물밀어가는사람소리는듯기만하여도흥성시러운거슬웨나만혼자가슴 에눈물을참을수업는고?

(<불노리 Bulnori> by Ju, Y.H., A poem in 『창조 Changjo』)

\footnotetext{
${ }^{8}$ Picture 10 is the cover of the 『창조 Changjo』 magazine.
} 
The punctuation marks used in magazines in this era were based on writers' preferences and writing styles rather than certain rules. Magazines in this era showed completely different aspects based on editors. Also, different writers and different pieces show different use of punctuation marks even in the same magazines. This shows that rules of using punctuation marks were not established at the time. As punctuation marks were used in newspapers and magazines like Independent News, people started to recognize punctuation marks. Then, there were attempts to standardize them in textbooks and grammar documents. In Pictures 8 12 we can find diversity of layout, especially in directions of the writing. Picture 8, picture 10 and picture 12 are traditional right-to-left direction. But picture 9 has the western style, going from left-to-right. Picture 11 is a mixture of the two directions. The usage of the punctuation marks during this time was diverse as the drection of writing. Eventually, punctuation marks had been established as one unified rule in $『$ 한글마춤법통일안』(Hanguelmachumpeop-tongiran, [Draft for the Unified Spelling System of Hanguel]). Current Korean punctuation marks are based on several editions of western punctuation marks enacted in Draft (한글마춤법통일안 (1933)). Current rules of punctuation marks have basically adopted western punctuation marks but overlooked Korean traditional punctuation marks (Table $3)$.

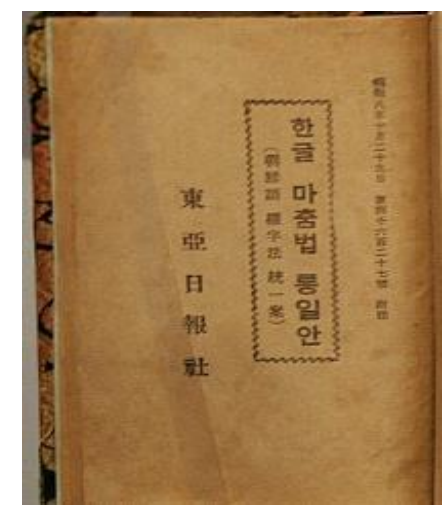

Picture 12: Draft for the unified spelling system of Hanguel. 
Table 3: Korean punctuation marks

\begin{tabular}{|c|c|c|}
\hline name & Contents & vertical writing \\
\hline $\begin{array}{l}\text { 마침표 } \\
\text { machim-pyo }\end{array}$ & $\begin{array}{l}\text { 온점 on-jeom ( . ) } \\
\text { 물음표 muleum-pyo (?) } \\
\text { 느낌표 neukimpyo (!) }\end{array}$ & 고리점 korit-jeom (。) \\
\hline $\begin{array}{l}\text { 쉼표 } \\
\text { shwim-pyo }\end{array}$ & $\begin{array}{l}\text { 반점 pan-jeom (, ) } \\
\text { 가운 뎃점 kaundet-jeom (・) } \\
\text { 쌍점 sang-jeom ( : ) } \\
\text { 빗금 pitkeum ( / ) }\end{array}$ & 모점 mo-jeom (、) \\
\hline $\begin{array}{l}\text { 따옴표 } \\
\text { taom-pyo }\end{array}$ & $\begin{array}{l}\text { 큰따옴표 keuntaom-pyo ( “ ” }) \\
\text { 작은따옴표 chakeuntaom-pyo ( ‘ }) \\
\text { 낫표 nat-pyo }(\lceil 」)\end{array}$ & $\begin{array}{l}\text { 겹낫표 kyeopna-tpyo } \\
(『 』)\end{array}$ \\
\hline $\begin{array}{l}\text { 묶음표 } \\
\text { mukkeum-pyo }\end{array}$ & $\begin{array}{l}\text { 소괄호 so-gwalho ( ( ) ), } \\
\text { 중괄호 chunh-gwalho (\{ \}) } \\
\text { 대괄호 te-gwalho ([ ]) }\end{array}$ & \\
\hline $\begin{array}{l}\text { 이음표 } \\
\text { ieum-pyo }\end{array}$ & $\begin{array}{l}\text { 줄표 chul-pyo (-) } \\
\text { 붙임표 putim-pyo }(-) \\
\text { 물결표 mulkyeol-pyo ( ) }\end{array}$ & \\
\hline $\begin{array}{l}\text { 드러냄표 } \\
\text { deureonem-pyo }\end{array}$ & 드러냄표 deureonem-pyo ( $\left.{ }^{*},{ }^{\circ}\right)$ & \\
\hline $\begin{array}{l}\text { 안드러냄표 } \\
\text { andeureonem-pyo }\end{array}$ & $\begin{array}{l}\text { 숨김표 sumgim-pyo }(\times \times, \bigcirc \bigcirc) \\
\text { 빠짐표 pajim-pyo }(\square) \\
\text { 줄임표 chulim-pyo }(\cdots \cdots \cdot)\end{array}$ & \\
\hline
\end{tabular}

The National Institute of The Korean Language constituted minimum punctuation marks that help writers communicate with readers. This shows the tendency of today's Korean academia that does not consider punctuation mark rules seriously. ${ }^{9}$ This is not just for the claims that punctuation marks are necessary for logical writings, but for the ideas regarding punctuation marks as a redundant feature when considering the characteristic of Korean to be pervasive.

Korean studies about punctuation marks, which mostly were one part of the Korean Language Policy, has so far focused on concept analysis supplement and punctuation mark imperfection. Concept of punctuation marks and their differences from general marks were studied by Lee (1996), Cha (1999), Sin (2009), Kim (2011), and specific functions of punctuation marks were suggested closely by Im et al. (2011) and Lee (2012).

\footnotetext{
${ }^{9}$ The koritjeom $\left(^{\circ}\right)$, appeared in vertical writing rule, had been used since the medieval time, the modern punctuation mark rule is directly influenced by modern punctuation marks of Japan and China.
} 
The different types of existing punctuation marks are not various as the previous figure shows. There are only two names, which are '- pyo 'and '- jeom', and their functions form unnecessary hierarchy. They show that there are dualistic names and functions. Unifying the punctuation mark rules without categorizing them hierarchically is one of the main arguments about the current rule of punctuation marks. However, Sin (2009) suggests to categorize them into two groups of 'reading-related marks' and 'writing-related marks' in order to make the system more efficient. According to the study, ' - jeom' is associated with reading-related marks, and '- pyo' is writingrelated. This argument seems to stem from the consideration of traditional punctuation marks, but the categorization makes it hard to embrace the function of interpretative aspect of traditional punctuation marks, which is the role they used to play.

\section{Conclusion: Implications of Studying Punctuation Systems}

Just like other conditions of literate life, punctuation marks also change as communication modes alter. The current Korean punctuation marks are the minimum marks utilized to assist reading. The reason why it is so has a strong relation to the unique features of Hangeul as a writing system, and it is also because people have put up with the degree of the agreement of speech and writing. However, the current phenomenon where various newly created marks are used in writing indicates that both readers and writers now want more than the normal marks. Nowadays, people expect more than literal meanings from letters and writings. This is why text messages are expected not to end with the conventional period (.) but instead with other signs, such as $\wedge \wedge$ and $\sim$, whereby additional information of the writer, for example, how they feel at that moment, is delivered. Advancement in technology has opened new ways to communicate. While these signs are classified as pseudo-language, they should be also discussed in view of punctuation marks, so long as they are employed in sentences and texts. Use of two different languages, Korean and Chinese, in the old days, necessitated the employments of the punctuation marks whose functions and kinds were different from modern-day punctuation marks. The development of 'kugyol' can be measured in this vein, and this particular system proposes that punctuation system does not always play supplementary roles in sentences. Examining the history of punctuation systems is of much significance, as it helps to correct and expand the concepts of the current punctuation system.

This work was supported by the National Research Foundation of Korea (NRF) Grant funded by the Korean Government (MEST) (NRF-2010-361-A00018). 


\section{References}

Cha, J. E. (1999). A Study on the Use, Education of book Sentential Punctuations. Korean Linguistics 9, 285-305.

Choi, H. (2011). On the name of punctuation as a terminology. Studies of Chinese \& KoreanHumanities 34, 201-230.

Dürscheid, C. (2004). Einführung in die Schriftlinguistik. Göttingen.

Im et al.(2011), Punctuation Guide (proposal), The National Institute of the Korean Language.

Kang, Y. O. (2009). A Study on the Punctuation in Documents of the Spring-Autumn and Warring States periods (春秋戰國時代), Journal of Chinese Language and Literature 45, 249-271.

Kim, I. K. (2011). A Reflective Approach to Korean Punctuation Marks. Poetics \& Linguistics 21, 73-97.

Kim, P. (1980). A study about the Origin of Korean Punctuation. Hankukhakbo 9, 106-124.

Kim, S. (2009). The Punctuation of Satobon Hwaeommuniyogyeol. The Research on Korean Language and Literature 53,123-148.

Lee, I. (1996). The Funtion of Korean Punctuation. Kwanakeomunyeongu 21, 19-40.

Lee, P. (1995). Pre-modern Punctuation in Korean. Kukje-eomun 16, 61-75

Lee, S.(2005). Special mark in the Qin Jian. Journal of Chinese Humanities 31,1-17.

Lee, S. (2006). A Study on Korean Punctuation Analysis of The Usages. Korean Education 74, 225-268.

Lee, S. J. (2002). A Search for Various marks in Old Korean Books. New Korean Life 12-4, 21 43.

Lee, Y. H. (2006). The Basic Research of the Korean Wooden Tablets. Sinseowon.

Park, J.G. (2007). Some Problems in Korean Punctuation Marks Regulation. Poetics \& Linguistics 14, 123-151.

Shin, H. (2009). A Study of Korean Punctuation Marks.Korean Language Education 128, 419454.

Son, W. (2011). The Documentary Culture Of Korean Wooden Slips and Calligraphic Style. Seowha Media.

Yi, S. (2012). Korean punctuation marks from various perspectives of Korean linguistics. Journal of Korean Linguistics 64, 185-215.

YU, Tl. (1990). A Study of Koreanphilology. Aseamunhwasa: Seoul.

Yoon, S. T. (2008). Signs and blank space from literary data of Silla. Journal of Kugyol Studies 21, 277-308.

Won, H.Y. (2010). Using Pattern and Characteristics of Sentence Codes At the Transition Periods to the Modern Times. Unpublished master's degree dissertation, Kook Min University. Seoul. 